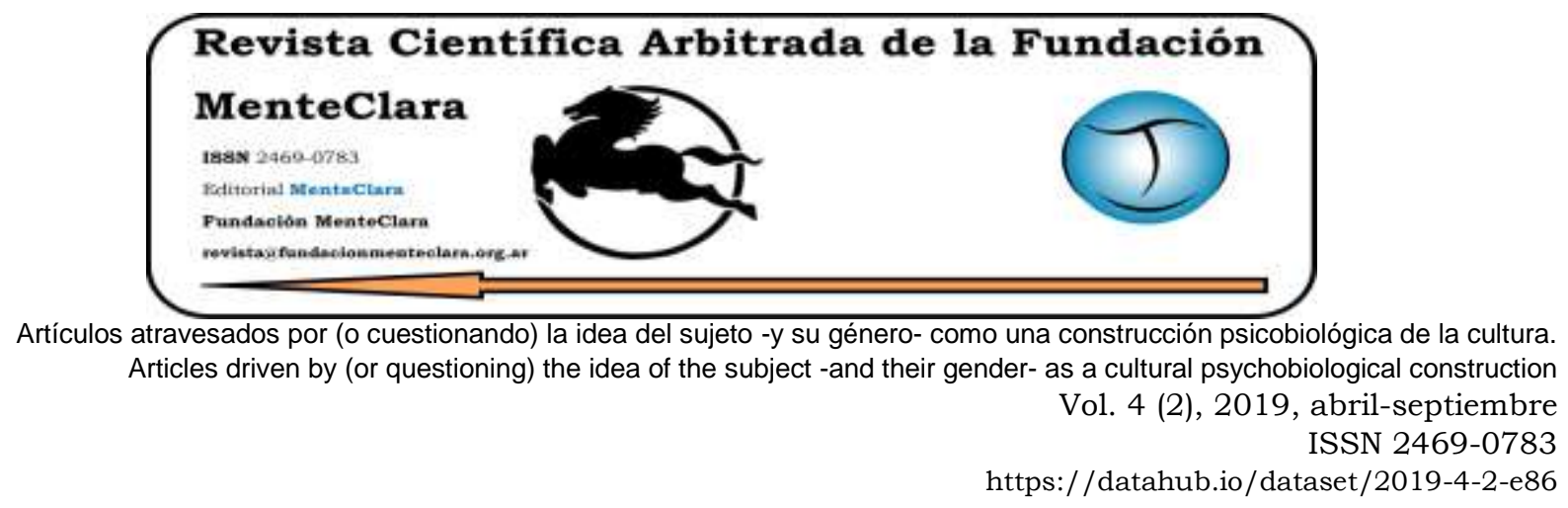

\title{
MIND AS KNOWER OF FORMS, AND AWARENESS AS THE KNOWER OF BEING: A PHENOMENOLOGICAL VIEW
}

\author{
LA MENTE COMO CONOCEDORA DE LAS FORMAS Y LA CONCIENCIA COMO \\ CONOCEDORA DEL SER: UNA VISIÓN FENOMENOLÓGICA
}

Rudolph Bauer rbauer@rsbauer.net

Center for Consciousness Studies and Washington Center for Phenomenological and Existential Psychotherapy Studies. United States of America

Cómo citar este articulo / Citation: Bauer R. (2019). "Mind As Knower of Forms, And Awareness as The Knower of Being: A Phenomenological View". Revista Científica Arbitrada de la Fundación MenteClara, 4(2) abril-septiembre 2019, 47-53.

DOI: https://doi.org/10.32351/rca.v4.2.86

Copyright: (C) 2019 RCAFMC. Este artículo de acceso abierto es distribuido bajo los términos de la licencia Creative Commons Attribution 4.0 International License (CC BY 4.0). Recibido: 02/07/2019. Aceptado: 16/07/2019 Publicación online: 30/10/2019

Conflicto de intereses: None to declare.

\begin{abstract}
This article phenomenologically describes our ontological situation and our two modes of knowing. There is the knowing of mind as the knower of forms and the knower of awareness as the knower of Being. This paper links and integrates the tantric Dzogchen view of the mind - awareness distinction within the continental phenomenological view of the mind- awareness distinction as expressed in the work of Heidegger and Merleau Ponty. This distinction of mind and awareness allows us to clarify the confusion about our knowing of forms and our knowing of Being. The paper emphasizes the intertwining of awareness and mind. When mind and awareness are in oneness, then the knower can know the Being-ness of being through a being. The person can know the duality of beings within the non duality of Being. And the person can know the non duality of Being within the duality of beings.
\end{abstract}




\section{Resumen}

Este artículo describe fenomenológicamente nuestra situación ontológica y nuestros dos modos de conocimiento. Existe el conocimiento de la mente como el conocedor de las formas y el conocedor de la conciencia como el conocedor del Ser. Este documento vincula e integra la visión tántrica Dzogchen de la distinción mente-conciencia con la visión fenomenológica europea de los siglos XIX y XX de la distinción menteconciencia expresada en el trabajo de Heidegger y Merleau Ponty. Esta distinción de mente y conciencia nos permite aclarar la confusión sobre nuestro conocimiento de las formas y nuestro conocimiento del Ser. El artículo enfatiza el entrelazamiento de la conciencia y la mente. Cuando la mente y la conciencia están en unidad, el conocedor puede conocer el Ser del ser a través de un ser. La persona puede conocer la dualidad de los seres dentro de la no dualidad del Ser. Y la persona puede conocer la no dualidad del Ser dentro de la dualidad de los seres.

Keywords: Tantra; Being; Consciousness; existence; duality; non-duality; nothingness; potential

Palabras Claves: Tantra; Ser; Consciencia; existencia; dualidad; no-dualidad; nadidad; potencial 


\section{Introduction}

We have two ways of knowing. Our mind knows forms, things, both subtle and gross. Faces, hands, buildings, trees, math formulas, mind knows subject and the mind knows otherness. The mind knows dualities, the mind knows me and you, us and them, and this and that. Mind knows time, mind knows the past, the present and the sense of the future. The mind knows things and entities, the mind knows beings, infinite numbers of beings and things. The mind knows difference. The mind thinks conceptually, feels affectively, imagines through imagery, the mind has sense and the mind has memory. The mind knows dualistically.

Awareness knows Being directly and awareness knows the being-ness of Beings directly. Being is not a being, and Being manifests beings. Being manifests beings, within beings, as their being. Being itself is not an entity, not a being. Being is non-duality. Being knows the non-duality of everything and anything. Being is oneness and pervasiveness. Being is openness. Being self-manifests as radiant light and Being is compassionate, creative resonance.

Being manifests duality, although Being is complete non-dual. By becoming aware of awareness, we experience primordial awareness which is the ground of beings, which is Being. Awareness is Being. Awareness is Being knowing itself. Being knows Being and the being-ness of all the beings. Awareness can be timeless as well as manifesting beings in time as time.

The mind knows time and awareness knows timelessness in time and beyond time. Being knows timeless in time and Being is timeless manifesting time. Being becomes everything and anything. Being selfmanifests as everything and anything. Being is no thingness. Being whose characteristic is openness, self-manifesting as radiance, light 
creating everything and anything. Being is no thingness and manifests everything and anything.

Being is light. Being is space and light. Being is openness and light. The light becomes energy and the energy becomes matter. The nature of matter is Being. Being manifests itself in us, as us, as our own awareness. Awareness is not a thing, awareness is no thingness. You and I are subjective knowingness which is awareness. Awareness is no thingness within the thingness of mind and body. Our awareness as knowingness is openness and radiance. Radiance illuminates and is the intimate resonance within everything and anything. This intimate resonance is the great compassion. Compassion is not simply the wishing goodness for everyone, compassion is the direct resonance with the goodness of Being in everyone and everything. Being is goodness. To experience the Beingness of beings including one own being is to experience the bliss of Being, the bliss of existence. Being appears and disappears as beings, but Being is neither born or dies. Being is.

Being manifests many, many dimensions. Being manifests life as Nirmanakaya, ordinary life. Being manifests the appearance and disappearance of beings. Being manifests Sambogakaya, the forms of light and the light of forms. Being always remains, since Being is timelessness. Timeless manifests in time as time. Being manifests in time as beings.

As their forms disappear the being-ness of the beings remain. Being is unborn and undying. It is amazing and really useful to know that Being itself is the source and manifests the immanent flow of all lived experience, your experience, your ongoing continuous lived experience. Being is the indivisible source of your ongoing lived experience, even at this very moment. Within all experience Being is manifesting, radiating 
and glowing. So every experience is the openness of Being. Every experience is the manifestation of Being.

So through duality of appearance of phenomenon we can experience the non-duality of Being. Being is not a distinct phenomenon from the stream of experience. Being shines through all experience, and the radiance of experience is the radiance of Being. Non-dual awareness is experienced within duality as openness, as appearance and as interrelatedness. Being is experienced through beings, our own being is the doorway of Being itself. Your own being is the doorway both for yourself and other beings.

The indivisibility of Being manifests both as the manifested phenomena and the knower of the phenomena. This Being is manifest in you as you, as awareness, as pure awareness. Being is manifested as phenomena, as your embodiment as flesh.

All experience is the self-manifestation of primordial awareness. Being is the ground of all beings. Being is primordial awareness. This selfmanifestation is immanence. All experience is the self-manifestation of primordial non-duality as duality. Being manifesting being within beings. Being is magical because it is beyond causality. Non-dual awareness and dualistic mind are intertwined. And so we can experientially bring our mind into this awareness continuum. Psychology cannot be extracted from Being. 


\section{Conclusion}

Subjectivity is primordial awareness manifesting within a being as Being itself. Primordial awareness is Being itself manifesting as subjectivity within the Being of beings. Subjectivity is the openness of Being itself in everything and anything. Being is openness. Being is potentiality, pure potentiality.

Human beings are the intertwining of Being within a being, the intertwining of awareness and mind. When mind and awareness are in oneness, then the knower can know the Being-ness of being through a being. The person can know duality within non-duality and non-duality within duality. A human being is the intertwining of thingness and no thingness, the intertwining of openness and thingness. 


\section{References}

Heidegger, M. (2014). Introduction to metaphysics. Yale University Press.

Heidegger, M. (1958). The question of being. Rowman \& Littlefield.

Merleau-Ponty, M. (1964). Indirect language and the voices of silence. Signs.

Lingpa, D. (2015). The Sole Essence of Clear Light, The Terma Revelations of Dudjom Lingpa, Translated by Lama Chonam and Sangye Khandro, Kama Term Publications, Boulder Colorado.

Lingpa, D. (2015). Dudjom Lingpa's Visions of The Great Perfection, The Vajra Essence, Vol.3, Translated by B.Alan Wallace.

Adamek, W. L. (2007). The Mystique of Transmission, New York: Columbia University Press.

Namkhai, N., \& Clemente, A. (1989). Dzogchen: The self-perfected state. London, England: Arkana. 